\title{
Does otolith structure reflect the nutritional condition of a fish larva? Comparison of otolith structure and biochemical index (RNA/DNA ratio) determined on cod larvae
}

\author{
C. Clemmesen*, T. Doan \\ Institut für Meereskunde an der Universität Kiel, Düsternbrooker Weg 20, D-24105 Kiel, Germany
}

\begin{abstract}
Cod larvae from laboratory rearing experiments aged from 1 to $12 \mathrm{~d}$ after hatching, both fed and deprived of food, were analysed. The number of increments on the otolith and the width of these increments were determined together with the RNA/DNA ratios on the same individual larva. Alizarin marking of the otoliths was performed to confirm the formation of daily increments. Cod larvae reared at $6^{\circ} \mathrm{C}$ formed the first ring right after hatching and deposited increments on a daily basis A comparison of the measurements between the right and the left lapillus showed that these can differ, if the radius is taken. The lapillae core showed especially high individual variability, whereas the sum of the increments did not differ between both lapilli. Until Day 10 after hatching, while the larvae were still feeding on their yolk, the external food situation did not affect the increment width of the lapilli or the RNA/DNA ratios. In larvae older than $10 \mathrm{~d}$ the width of the daily increments was dependent on the nutritional situation and RNA/DNA ratios decreased in starving larvae in comparison to feeding larvae. RNA/DNA ratios and increment widths were correlated
\end{abstract}

KEY WORDS: Nutritional condition - RNA/DNA ratio - Otolith microstructure - Recruitment Cod larvae

\section{INTRODUCTION}

Fluctuations in the size of fish populations may occur as a consequence of changes in the annual influx of young or recruiting fish. Recruitment variations are compounded by the effects of human exploitation and often attributed to the effects of environmental variations on the survival of egg and larval stages. The success or failure of annual recruitment can have a number of different abiotic and biotic causes. High mortality rate during early stages is considered one of the major factors causing stock fluctuations. The lack of food or a mismatch in the distribution of larval fish and food organisms are principal causes of poor year class strength (Hjort 1914, Hunter 1976, Lasker 1978, Hewitt et al. 1985).

•E-mail: cclemmesen@ifm.uni-kiel.d400.de
The relationship between RNA and DNA is an index of a cell's metabolic intensity and has been used to measure recent growth in fish (Buckley 1984, Buckley \& Lough 1987, Bulow 1987, Hovenkamp 1990, Hovenkamp \& Witte 1991) and has proved to be a useful indicator of nutritional condition, as shown in several larval fish studies (Buckley 1980, 1984, Martin et al. 1985, Fukuda et al. 1986, Buckley \& Lough 1987. Clemmesen 1987, 1994, Raae et al. 1988, Robinson \& Ware 1988).

Otolith structures reflecting daily patterns were described by Panella $(1971,1974)$ and experimentally proven by Struhsacker \& Uchiyama (1976). Brothers et al. (1976) used otolith increment structure to determine the age of larvae and juvenile fish. The environment experienced by a larva will influence its otolith structure, as was shown in several laboratory experiments (Panella 1980, Neilson \& Geen 1982, Radtke \& Dean 1982, Berghahn \& Karakiri 1990, Mugiya \& Oka 1991) 
It is known that environmental factors such as constant darkness (Dale 1984) or too high temperatures (Mosegaard et al. 1988) can affect the otolith increment structure. Based on the assumption that somatic growth is reflected in the growth of the otolith, a larva that is growing well should deposit a wider daily increment than a starving larva with slower growth. Maillet \& Checkley (1990) and Zhang \& Runham (1992) determined changes in the otolith structure in starving laboratory-reared Atlantic menhaden and Oreochronis nilotilus. Studies on Norwegian spring-spawning herring and North Sea autumn-spawning herring have shown the potential of using otolith microstructure in recruitment research (Fossum \& Moksness 1993).

All condition indices determine the nutritional condition at the time of catch, reflecting the situation of the last hours, days or weeks before catching, depending on the methods used. It is sometimes difficult to assess if the larva's condition is improving or deteriorating. RNA/DNA ratios are commonly used to backcalculate and to forecast the growth and survival potential of larvae in order to help predict recruitment. The validity of the RNA/DNA ratio can be improved by incorporating otolith increment structure studies (daily increment studies) on some subsamples, in order to have the growth history of the larvae as well as the condition at catch.

The aim of this study was to combine otolith microstructure analysis and RNA/DNA ratio determination on the same individual larva to compare the effect of food deprivation on the width of the daily increment and the RNA/DNA ratio and evaluate the potential use of this combination for recruitment research.

\section{MATERIALS AND METHODS}

Cod larvae (Gadus morhua) were reared in the Havsfiskelaboratoriet Lysekil, Sweden, from 3 to 27 May 1994. Adult cod caught in November 1993 in the Bornholm Basin were transported to Lysekil, adapted to the higher salinity $(30 \mathrm{ppm})$ and kept in $10000 \mathrm{l}$ tanks at 6 to $7^{\circ} \mathrm{C}$ as brood stock for the experiments. Cod spawned naturally. The fertilized eggs were transferred into $100 \mathrm{l}$ tanks using a $300 \mu \mathrm{m}$ plankton net. The eggs floated on the surface and were moved by a

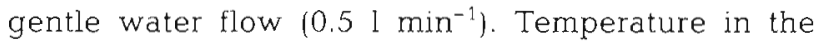
incubation tank was 6 to $7^{\circ} \mathrm{C}$. Larvae hatched after $13 \mathrm{~d}$ and were transferred to $100 \mathrm{l}$ rearing tanks. Larvae were fed starting on Day 4 after hatching with the rotifer Brachionus plicatilis reared on the flagellate Isochrysis galbana. Temperature throughout the experiment varied from 6 to $7.5^{\circ} \mathrm{C}$ and salinity was between 33 and 34 ppm. Tanks were illuminated on a 16:8 h day/night cycle. Larvae were fed 3 times a day at 08:00, 12:00 and 16:00 h at a density of 0.65 Brachionus $\mathrm{ml}^{-1}$. The daily food ration amounted to $2 \mathrm{Bra}$ chionus $\mathrm{ml}^{-1}$ Due to unexpectedly high mortality rates the experiments had to be terminated after Day 12 after hatching

For marking of the otoliths 100 larvae were transferred to a $5 \mathrm{l}$ bucket containing Alizarin $\left(50 \mathrm{mg} \mathrm{l}^{-1}\right.$; Tsukomoto 1988, Blom et al. 1994, Geffen 1995) on Day 4 after hatching and kept there for $16 \mathrm{~h}$ to let the Alizarin set a fluorescent mark on the increment formed that day. After that the larvae were carefully transferred to clean sea water. Samples of the larvae were taken daily starting on Day 4 at 11:00 h after the larvae had been fed at 08:00 h. Five larvae per sample were taken, transferred into Eppendorf vials and stored in liquid nitrogen until the end of the experiment. After that the samples were stored in a $-70^{\circ} \mathrm{C}$ freezer and left there until otolith and RNA/DNA analysis was performed.

The analyses of the RNA and DNA content of the larva and the dissection of the otolith were performed simultaneously. Larvae were thawed, and the standard length was measured. Sagittae and lapilli were identified using a polarisation filter attached to a binocular. Since the lapilli in cod larvae are initially the larger otoliths and therefore easier to extract and read than the sagittae, they were dissected from the individuals. After age $25 \mathrm{~d}$, as the rate of otolith growth of the sagitta increases, it then becomes the most accurate otolith to us for estimating age and growth rates (Bergstad 1984). The lapilli were located using a dissecting microscope with cross-polarized light and dissected from the larvae using fine insect-needles. Adhering tissue was carefully scraped away from the otolith, which was then rinsed with distilled water. After 5 to $10 \mathrm{~min}$ of drying at room temperature the lapilli were mounted on glass slides using fingernail polish. A circle was drawn on the slide around the otolith to facilitate future manipulation and analysis (Stevensen \& Campana 1992). It was not necessary to polish the otoliths due to the young age of the sampled larvae.

The larva without the lapilli was put into an Eppendorf vial kept on ice. After the lapilli of 5 larvae had been dissected (necessary dissecting time: $30 \mathrm{~min}$ ) the RNA/DNA analysis was performed according to the method of Clemmesen $(1988,1993)$ using a specific nucleic acid fluorescent dye-Ethidium Bromide (EB) - for DNA and RNA. In order to measure the DNA content of a sample, RNA was enzymatically digested with RNase and the remaining DNA was determined with EB.

Measurements on the lapilli were performed using a digitalized computer-aided video system with a CCD camera (Panasonic WVCL 700) connected to a fluores- 
cence microscope (Zeiss Axioplan) at $1000 \times$ magnification. Both lapilli were used for the analysis, and the radii, number of increments and width were measured 4 times in 4 different directions on the lapilli and the means were calculated.

\section{RESULTS}

To determine the accuracy of the age determination using the number of otolith increments, the results of the readings on the lapilli were compared with the known age of the laboratory-reared cod larvae (Fig. 1). Out of 150 analysed lapilli, 147 showed the deposition of a daily increment starting on the day of hatch. Only $2 \%$ of the analysed lapilli showed 1 ring less than expected. A $16 \mathrm{~h}$ treatment with Alizarin resulted in an orange increment deposited on the day of marking. It could later be identified under the fluorescence microscope. The number of increments formed after the Alizarin-marked increment was counted and compared with the known number of days passed since the marking. The rings after marking are deposited on a daily basis and give further confirmation of the formation of the first increment on the day of hatching (Fig 2).

A comparison of left and right lapilli showed that the radius or diameter of the lapilli not only depends on the growth of the daily increments but is very much affected by the size of the lapilli's core. The size distribution of the lapilli cores between the left and the right

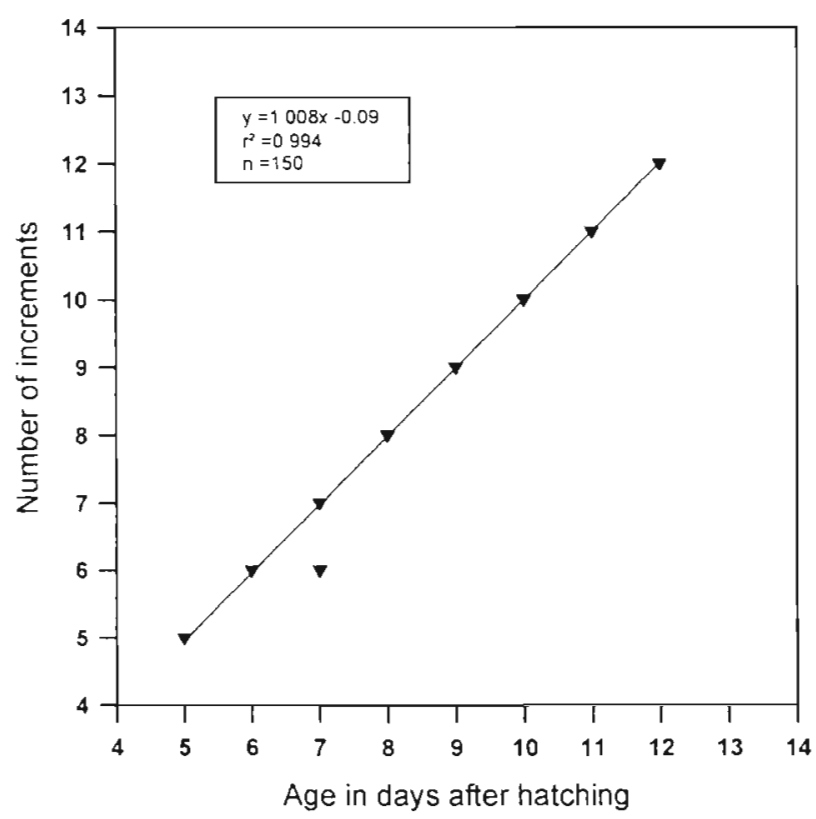

Fig. 1. Gadus morhua. Relation between number of increments and known age of laboratory-reared cod larvae

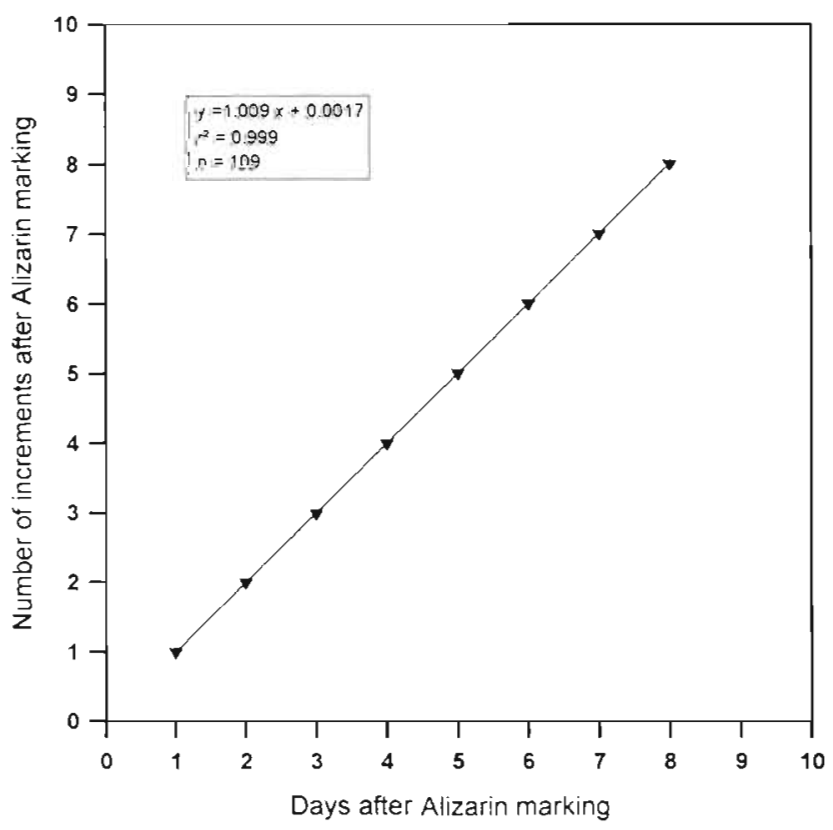

Fig. 2. Gadus morhua. Confirmation of daily increment deposition. Relation between number of increments after Alizarin marking and days after Alizarin marking of laboratory-reared cod larvae

side varied between 4.5 and $13 \mu \mathrm{m}$, but did not show a statistically different distribution between left and right side ( $t$-test, $\mathrm{p}<0.05$ ). The comparison of the lapilli core of the left and the right lapilli measured on the same individual larva revealed that there were differences in the size of the core (Fig. 3). A similar picture appeared when the radius of the left and the right lapilli on the same larva was compared (Fig. 4). In comparison the sum of the increments deposited on the left and the right lapillae did not differ (Fig. 5). The variability between the size of the left and right lapilli was mainly caused by the difference in the size of the core.

To evaluate the effect of food availability or food withdrawal on the width of the daily otolith increments a comparison of the size of the increments of all analysed fed and starved larvae showing mean values and standard deviations is presented (Fig. 6). The variability in the size of the daily increments is high in both groups but a comparison of the mean values shows a trend of increasing increment width in fed larvae starting on Day 7 and decreasing width of the increments in the starved group.

From Day 4 to Day 7 the RNA/DNA ratio decreased from a value of 7 to below 2 (Fig. 7). This seems to be due to yolk absorption causing a decrease in condition. Between Day 7 and Day 12 the RNA/DNA ratio in the starved group decreased further, in contrast to that of the fed group, which slightly increased. The effect of food availability started to be visible on Day 11 (Fig. 7). For analysis of the relationship between mean RNA/ 


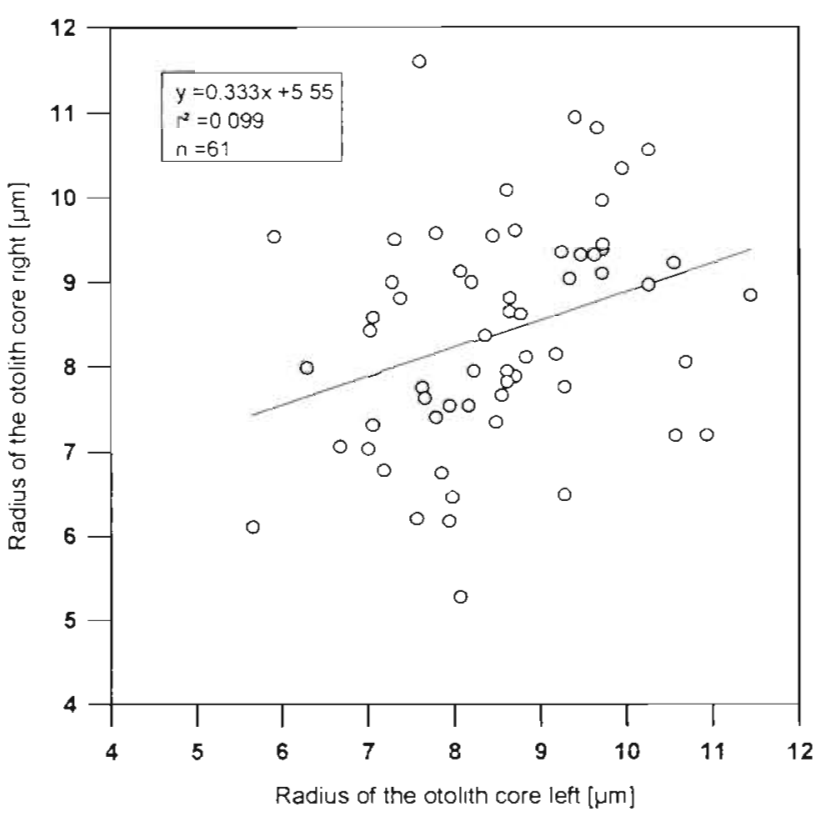

Fig. 3. Gadus morhua. Correlations between radii of otolith cores of left and right lapilli. Values are means calculated from 4 measurements in 4 different directions on the lapilli of 4 to $12 \mathrm{~d}$ old cod larvae. A linear regression model was fitted to the data

DNA ratios and mean relative lapilli growth the values for fed and starved larvae are given in Fig. 8. The relative lapillus growth was calculated by setting the width

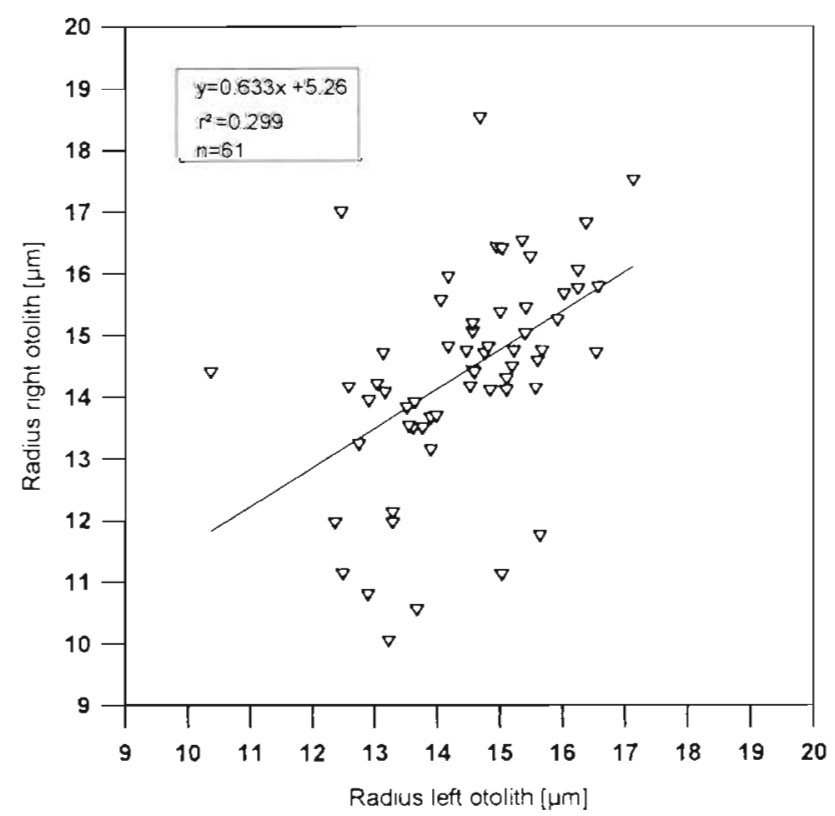

Fig. 4. Gadus morhua. Correlations between radii of left and right lapilli. Values are means calculated from 4 measurements in 4 different directions on the lapilli of 4 to $12 \mathrm{~d}$ old cod larvae. A linear regression model was fitted to the data

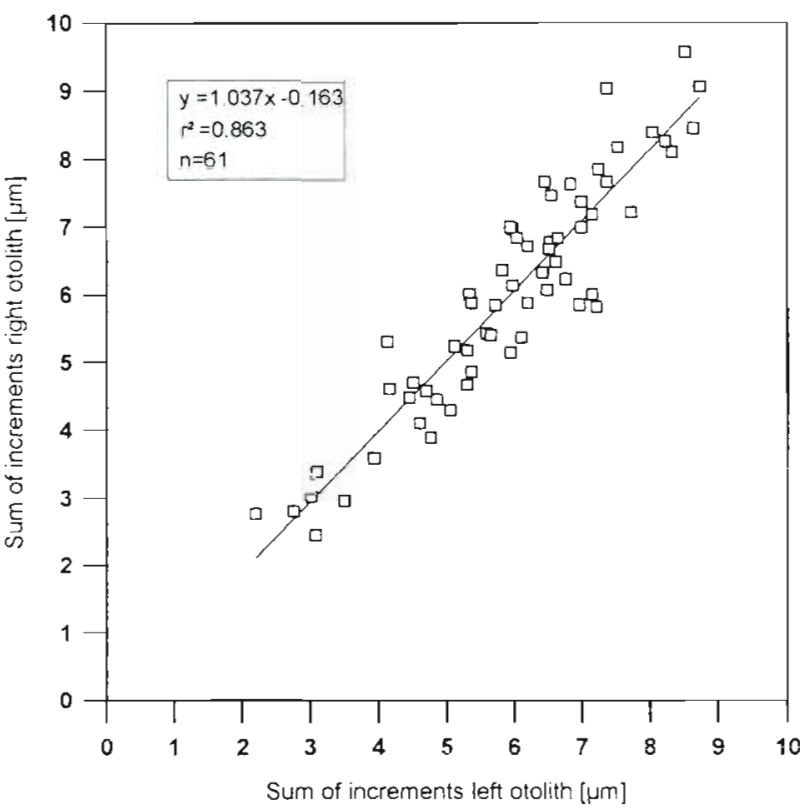

Fig. 5. Gadus morhua. Correlations between sums of increments of left and right lapilli. Values are means calculated from 4 measurements in 4 different directions on the lapilii of 4 to $12 \mathrm{~d}$ old cod larvae. A linear regression model was fitted to the data

of increment 4 (Day 5) to a value of 1 and calculating the relative growth of the following increments in relation to that value. Every data point represents the mean of 4 or 5 larvae. (The dataset for this figure is

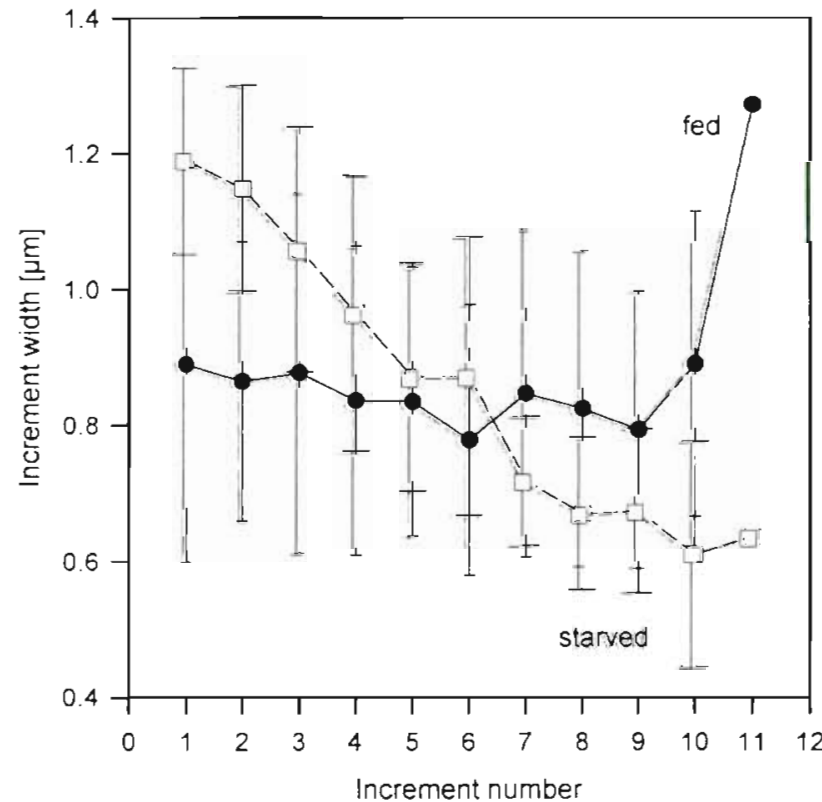

Fig. 6. Gadus morhua. Mean increment width of 59 fed cod larvae compared to 27 starved cod larvae. Error bars give the standard deviation 


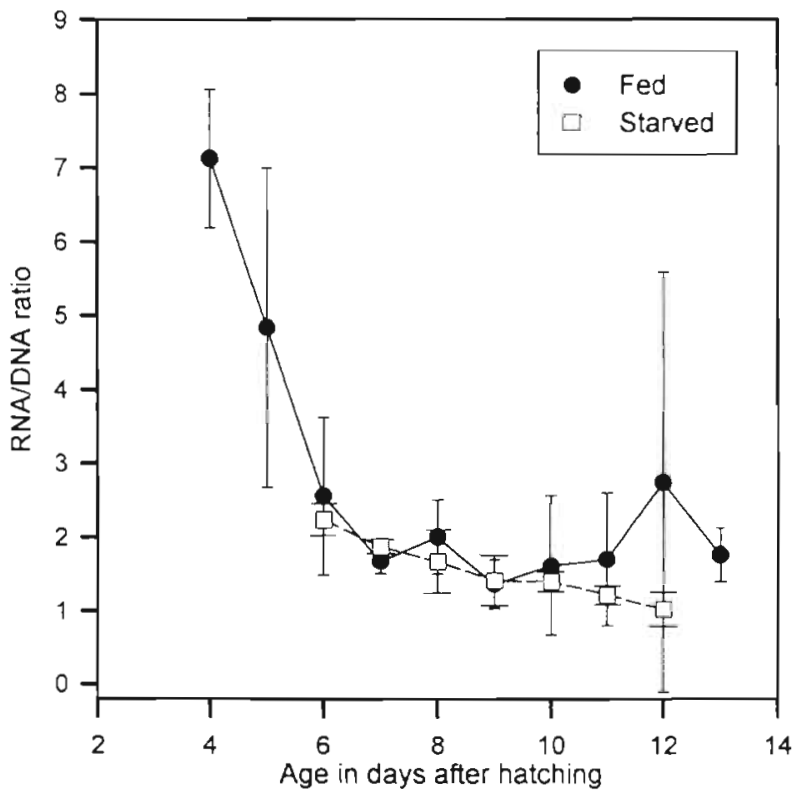

Fig. 7 Gadus morhua. RNA/DNA ratios of cod larvae in relation to age and feeding situation. Starving larvae $(n=45)$ were deprived of food starting on Day 4 and Day 7 and compared to fed larvae ( $n=86)$. Error bars give the standard deviation

based on the Alizarin marking experiment and is reduced compared to the dataset shown in Fig. 7.) The reason for taking the width of increment 4 is that the switch from yolk absorption to external feeding in cod larvae at the given temperature starts at that age (Laurence 1978, Radtke \& Waiwood 1980, Solberg \& Tilseth 1984, Fossum 1986). The growth observed in the following increments therefore should be reacting to external food supply. The relative growth of the lapilli of the starved larvae was reduced compared to the fed group. The RNA/DNA ratios of fed larvae doubled between Day 6 and Day 12, whereas the value in the starved group was reduced to half of the ratio of starved larvae at the beginning (Fig. 8). It can be seen that the feeding larvae have higher RNA/DNA ratios and a higher growth of the daily increments, showing that the RNA/DNA ratio and the increment growth are coupled.

\section{DISCUSSION}

The study showed that cod larvae form the first increment on the otolith on the day of hatching. Age determination based on increment numbers in comparison to known laboratory age as well as Alizarin marking results confirmed the deposition of daily increments. These results are in agreement with increment formation studies in cod larvae by Dale (1984)

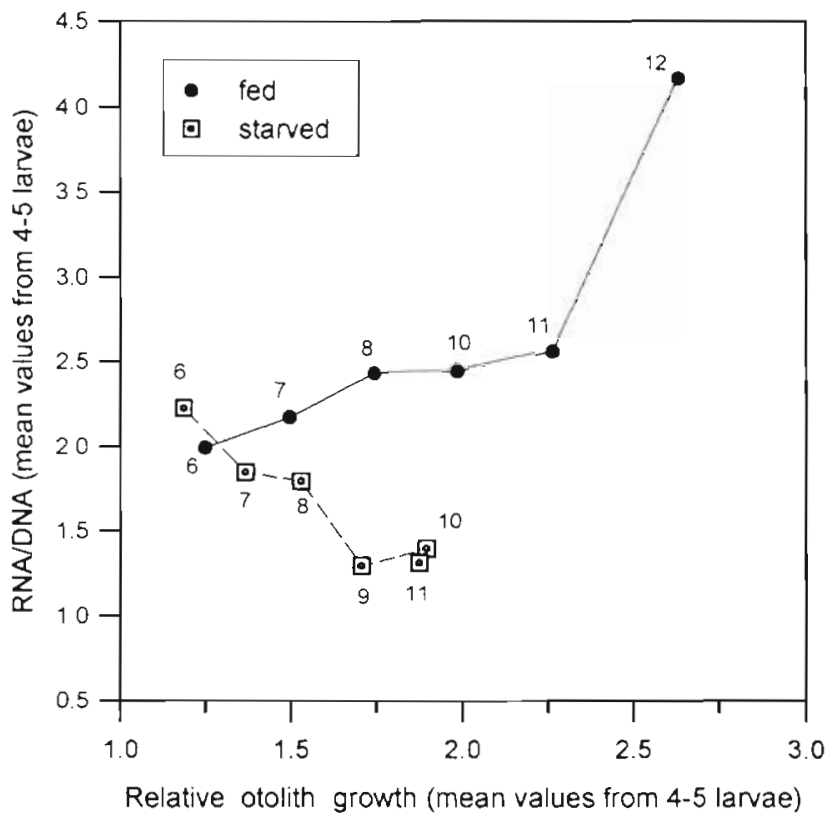

Fig. 8. Gadus morhua. Relation between relative otolith growth of fed and starved cod larvae and RNA/DNA ratios. For calculation of relative growth the width of ring number 4 was set to 1 . Numbers give age in days

and Geffen (1995). Neilson \& Geen (1982) showed differences in the size of the otoliths taken from the left or right labyrinth in salmonids (Oncorhynchus tshawytscha). Comparison of left and right lapilli in this study clearly showed that care has to be taken when measuring the total size (radius), since differences between left and right otoliths occurred. These differences did not result from the growth of the daily increments, but depended on the size of the otolith core at the time of hatch. Individual egg development as well as environmental factors might affect the size of the core. Influences on the formation of the otolith core should be further analysed.

The growth of the increments was affected by the availability of external food sources and differed between feeding and starving larvae starting on Day 7. The RNA/DNA ratio started to increase on Day 7 in the feeding group, becoming more pronounced on Day 11 , whereas the RNA/DNA content in the starved group decreased and also reflected the situation found in the otolith microstructure. During the yolksac phase no clear differences between feeding and starving larvae could be found, which is in agreement with results discussed in Clemmesen (1994). Results for RNA/DNA ratios shown here are in agreement with studies on cod larvae by Buckley $(1979)$ and results for herring larvae by Clemmesen $(1987,1994)$.

Alizarin marking did not affect the RNA and DNA measurements, since the concentrations of nucleic 
acids determined on marked and unmarked cod larvae did not differ. Unfortunately, sampling of the larvae could not be performed after Day 12. It is postulated that the trends shown in this study would have been much more significant if samples from older larvae had been available. Future studies should increase the sampling protocol up to an age of $21 \mathrm{~d}$ at least.

Biochemical indicators (RNA/DNA ratios) have been used to demonstrate starvation mortality in the field, and correlations between food availability and larval condition have been found (Setzler-Hamilton et al. 1987, Frank \& McRuer 1989, Canino et al. 1991, Theilacker et al. 1996). A positive relationship of RNA/ DNA ratio and prey abundance has been shown for striped bass larvae Morone saxatilis (Martin et al. 1985 ) and Atlantic cod Gadus morhua and haddock Melanogrammus aeglefinus larvae (Buckley \& Lough 1987). In field studies of condition indices in wild juvenile cod, recent otolith growth was not highly correlated with fish growth, but it was significantly related to zooplankton biomass, therefore presumably responding to feeding condition (Suthers et al. 1992).

First observations showing the relationship between growth rates over the last $5 \mathrm{~d}$ (as determined from the width of otolith daily increments) and protein growth rates based on nucleic acid determinations are available for North Sea plaice (Hovenkamp 1990), but have not been performed on the same individual larva. To our knowlegde this study is one of the first to determine otolith microstructure and RNA/DNA ratio analysis on the same larva. After yolk absorption the effect of an external food supply could be measured. The trend started to be visible on Day 7 and increased on Day 11 for RNA/DNA ratios as well as otolith microstructure analysis. High RNA/DNA ratios were coupled with greater increment width in fed larvae. Lower RNA/DNA ratios and smaller increment widths were found in starved larvae. Mosegaard et al. (1988) found uncoupling between somatic and otolith growth rates at hyperoptimal temperatures and therefore suggested that metabolic activity, not necessarily somatic growth rate, governs otolith growth rate. Somatic growth rate results mainly from the balance between protein synthesis and degradation, and hyperoptimal temperatures would accelerate both components, especially degradation, resulting in no somatic growth (Houlihan et al. 1988). However since somatic growth is comparable with components from metabolic rates within the range of optimal temperatures, the RNA/DNA ratio, an index of protein biosynthesis, will be a reflection of metabolic components at an appropriate temperature. Therefore it appears reasonable to use this ratio for examining the relationship between somatic and otolith growth rates, even if otolith growth is a function of metabolic rate.
By coupling RNA/DNA ratio determinations and otolith increment structure analysis on the same larva, it should be possible to determine whether the larva's condition is improving or deteriorating. The validity of these studies for the recruitment problem could be further improved. Whether the findings in this study, determined on laboratory-reared larvae, can also be found in field-caught larvae has to be further evaluated. Results by Clemmesen (1996) on field caught anchovy Engraulis anchoita larvae revealed that the sum of the last increments was correlated with the RNA/DNA ratio, meaning that it should be possible to determine the effect of lack of food in the wild by a combination of biochemical and otolith studies.

Acknowledgements. We thank the staff of the fishery department of the University of Marine Sciences in Kiel and the staff at the Institute of Marine Research in Lysekil for their support Special thanks to Jana Pickova for rearing of the cod larvae and sharing her expertise. We thank Karin Burkert for helping in the laboratory. We are indebted to Prof. Dr D. Schnack for his support. Partial funding was provided by the Institute in Kiel, the Deutsche Forschungsgemeinschaft (DFG, NE 99/ 23-1) and the European Union (EU-AIR 294 1226).

\section{LITERATURE CITED}

Berghahn R, Karakiri M (1990) Experimental induction of biological tags in otoliths of O-group plaice Pleuronectes platessa by starvation, temperature and UV-B radiation Mar Ecol Prog Ser 67: 227-233

Bergstad OA (1984) A relationship between the number of growth increments on the otoliths and age of larval and juvenile cod, Gadus morhua L. Flodevigen Rapportser 1. $251-272$

Blom G, Nordeide J, Svasand T, Borge A (1994) Application of two fluorescent chemicals, alizarin complexone and alizarin red S, to mark otoliths of Atlantic cod, Gadus morhua L. Aquacult Fish Manage 25 (Suppl 1):229-243

Brothers EB, Mathews CP, Lasker R (1976) Daily growth increments in otoliths from larval and adult fishes. Fish Bull US 74:1-8

Buckley LJ (1979) Relationship between RNA/DNA ratio, prey density and growth rate in Atlantic cod (Gadus morhua) larvae. J Fish Res Bd Can 36:1497-1502

Buckley LJ (1980) Changes in the ribonucleic acid, deoxyribonucleic acld and protein content during ontogenesis in winter flounder, Pseudopleuronectes americanus, and the effect of starvation. Fish Bull US 77:703-708

Buckley LJ (1984) RNA/DNA ratio: an index of larval fish growth in the sea. Mar Biol 80:291-298

Buckley LJ, Lough RG (1987) Recent growth, chemical composition and prey field of haddock (Melanogrammus aeglefinus) and cod (Gadus morhua) larvae and post larvae on Georges Bank, May 1983. Can J Fish Aquat Sci $44: 14-25$

Bulow FJ (1987) RNA:DNA ratios as indicators of growth in fish: a review. In: Summerfelt RC, Hall GE (eds) Age and growth of fish. Iowa State University Press, Ames, p 45-64

Canino MF, Bailey KM, Incze LS (1991) Temporal and geographic differences in feeding and nutritional condition of walleye pollock larvae Theragra chalcogramma in She. lıkof Strait, Gulf of Alaska. Mar Ecol Prog Ser 79:27-35 
Clemmesen C (1987) Laboratory studies on RNA/DNA ratios of starved and fed herring (Clupea harengus) and turbot (Scophthalmus maximus) larvae. J Cons Int Explor Mer 43 $122-128$

Clemmesen C (1988) A RNA and DNA fluorescence technique to evaluate the nutritional condition of individual marine fish larvae. Meeresforsch 32:134-143

Clemmesen C (1993) Improvements in the fluorimetric determination of the RNA and DNA content of individual manne fish larvae. Mar Ecol Prog Ser 100:177-183

Clemmesen C (1994) The effect of food availability, age and size on the RNA/DNA ratio of individually measured herring larvae: laboratory calibration. Mar Biol 118:337-382

Clemmesen C (1996) Importance and limits of RNA/DNA ratios as a measure of nutritional condition in fish larvae. In: Watanabe Y, Yamashita Y, Oozeki Y (eds) Survival strategies in early life stages of marine resources. Proceedings of an international workshop, Yokohama, Japan, 11-14 October 1994. A.A. Balkema, Rotterdam, p 67-82

Dale $T$ (1984) Embryogenesis and growth of otoliths in the cod (Gadus morhua L.). Flødevigen Rapportser 1:231-251

Fossum P (1986) A staging system for larval cod (Gadus morhua L.). Fisk Dir Skr Havunders 18:69-76

Fossum P, Moksness E (1993) A study of spring- and autumnspawned herring (Clupea harengus L.) larvae in the Norwegian coastal current during spring 1990. Fish Oceanogr $2: 2: 73-81$

Frank KT, McRuer JK (1989) Nutritional status of fieldcollected haddock (Melanogrammus aeglefinus) larvae from southwestern Nova Scotia: an assessment based on morphometric and vertical distribution data. Can J Fish Aquat Sci 46 (Suppl 1):125-133

Fukuda M, Nakano H, Yamamoto K (1986) Biochemical changes in Pacific herring during early developmental stages. Bull Fac Fish Hokkaido Univ 37(1):30-37

Geffen AJ (1995) Growth and otolith microstructure of cod (Gadus morhua L.) larvae. J Plankton Res 17(4):783-800

Hewitt RP , Theilacker GH, Lo NCH (1985) Causes of mortality in young jack mackerel. Mar Ecol Prog Ser 26:1-10

Hjort J (1914) Fluctuations in the great fisheries of Northern Europe viewed in the light of biological research. Rapp P-V Réun Cons Perm Int Explor Mer 160:1-228

Houlihan DF, Hall SJ, Gray C, Noble BS (1988) Growth rate and protein turnover in Atlantic cod, Gadus morhua. Can J Fish Aquat Sci 45:951-964

Hovenkamp $F$ (1990) Growth differences in larval plaice (Pleuronectes platessa L.) in the Southern Bight of the North Sea as indicated by otolith increments and RNA/ DNA ratios. Mar Ecol Prog Ser 70:105-116

Hovenkamp F, Witte JIJ (1991) Growth, otolith growth and RNA/DNA ratios of larval plaice Pleuronectes platessa in the North Sea 1987 to 1989. Mar Ecol Prog Ser 58:201-215

Hunter JR (1976) Report of a colloquium on larval fish mortality studies in their relation to fisheries research, Jan. 1975 NOAA. Tech Rep US Dept Commerce NMFS Circ 395:1-5

Lasker $\mathrm{R}$ (1978) The relation between oceanographic conditions and larval anchovy food in the California current identification of factors contributing to recruitment failure Rapp P-V Réun Cons Int Explor Mer 173:212-230

Laurence GC (1978) Comparative growth, respiration and delayed feeding abilities of larval cod (Gadus morhua) and haddock (Melanogrammus aeglefinus) as influenced by temperature during laboratory studies. Mar Biol 50:1-7

Maillet GL, Checkley DM (1990) Effects of starvation on the frequency of formation and width of growth increments in sagittae of laboratory reared Atlantic menhaden Brevoor- tia tyrannus larvae. Fish Bull US 88:155-165

Martın FD, Wright DA, Means JC, Setzler Hamilton EF (1985) Importance of food supply to nutritional state of larval striped bass in the Potomac river estuary. Trans Am Fish Soc 114:137-145

Mosegaard H, Svedang H, Taberman K (1988) Uncoupling of somatic otolith growth rates in arctic charr (Salvelinus alpinus) as an effect of differences in temperature response. Can J Fish Aquat Sci 45:1514-1524

Mugiya Y, Oka H (1991) Biochemical relationship between otolith and somatic growth in the rainbow trout Oncorhynchus mykiss: consequence of starvation, resumed feeding and diel variations. Fish Bull US 89:239-245

Neilson JD, Geen GH (1982) Otoliths of chinook salmon (Oncorynchus tshawytscha): dally growth increments and factors influencing their production. Can J Fish Aquat Sci $39: 1340-1347$

Panella G (1971) Fish otoliths: daily growth layers and periodical patterns. Science 173:1124-1127

Panella G (1974) Otolith growth pattern: an aid in age determination in temperate and tropical fishes. In: TB Bagenal (ed) The aging of fish. Unwin Bros Ltd, Surrey, p 28-39

Panella G (1980) Growth patterns in fish sagittae. In: Rhodes DC, Lutz RA (eds) Skeletal growth of aquatic organisms: biological records of environmental change. Plenum Press, New York, p 519-560

Raae A.J, Opstad I, Kvenseth P, Walther BT (1988) RNA, DNA and protein during early development in feeding and starved cod (Gadus morhua L.) larvae. Aquaculture 73 : $247-259$

Radtke RL, Dean JM (1982) Increment formation in the otoliths of embryos. larvae and juveniles of the mummichog, Fundulus heteroclitus. Fish Bull US 80:201-215

Radtke RL, Waiwood KG (1980) Otolith formation and body shrinkage due to fixation in larval cod (Gadus morhua L.) Can Tech Rep Fish Aquat Sci 929:1-10

Robinson SMC, Ware DM (1988) Ontogenetic development of growth rates in larval Pacific herring, Clupea harengus pallasi, measured with RNA-DNA ratios in the Strait of Georgia, British Columbia. Can J Fish Aquat Sci 45: $1422-1429$

Setzler-Hamilton EM, Wright F, Martin FD, Millsaps CV Whitlow $S$ (1987) Analysis of nutritional condition and its use in predicting striped bass recruitment: field studies. Am Fish Soc Symp 2:115-128

Solberg T, Tilseth S (1984) Growth and energy consumption in yolksac larvae of cod (Gadus morhua L.). Fledevigen Rapportser 1:145-166

Stevenson DK, Campana SE (1992) Otolith microstructure examınation and analysis. Can Spec Publ Fish Aquat Sci 117

Struhsacker P, Uchiyama J H (1976) Age and growth of the nehu Stophorus pupureus (Pisces: Engraulidae), from the Hawaiian Islands as indicated by daily growth increments of sagittae. Fish Bull US 74:9-17

Suthers IM, Fraser A, Frank KT (1992) Comparison of lipid, otolith and morphometric condition indices of pelagic juvenile cod Gadus morhua from the Canadian Atlantic. Mar Ecol Prog Ser 84:31-40.

Theilacker GH, Bailey KM, Canino MF, Porter SM (1996) Variations in larval walleye pollock feeding and condition: a synthesis. Fish Oceanogr 5(1):112-123

Tsukomoto K (1988) Otolith tagging of ayu embryo with fluorescent substances. Nippon Suisan Gakk 54(8):1289-1295

Zhang Z, Runham NW (1992) Effects of food radiation and temperature level on the growth of Oreochronis niloticus L. and their otoliths. J Fish Biol 40:341-349 